\section{Verdopplung der Bauchaorta: eine sehr seltene angeborene Anomalie, aber ein häufiger Ultraschall-Artefakt}

\section{Einleitung}

Bei einer Ultraschalluntersuchung richtet man Schallwellen auf einen bestimmten Bereich des Körpers und die reflektierten Schallwellen werden verwendet, Bilder der untersuchten anatomischen Strukturen zu erzeugen. Diese Echos können durch vielfältige Einflüsse modifiziert werden: durch Gewebe unterschiedlicher Zusammensetzung, Dichte und Abschwächung sowie durch Übergangsbereiche zwischen Geweben unterschiedlicher Gestalt, Größe und Ausrichtung. Diese Modifikationen können zahlreiche Artefakte hervorrufen, die leicht zu diagnostischen Irrtümern führen, wenn sie nicht erkannt werden.

Wir berichten hier über ein Bildverdopplungs-Artefakt, das von einem erfahrenen Ultraschalldiagnostiker leicht erkannt wird, für einen unerfahrenen Untersucher jedoch eine Herausforderung darstellen kann.

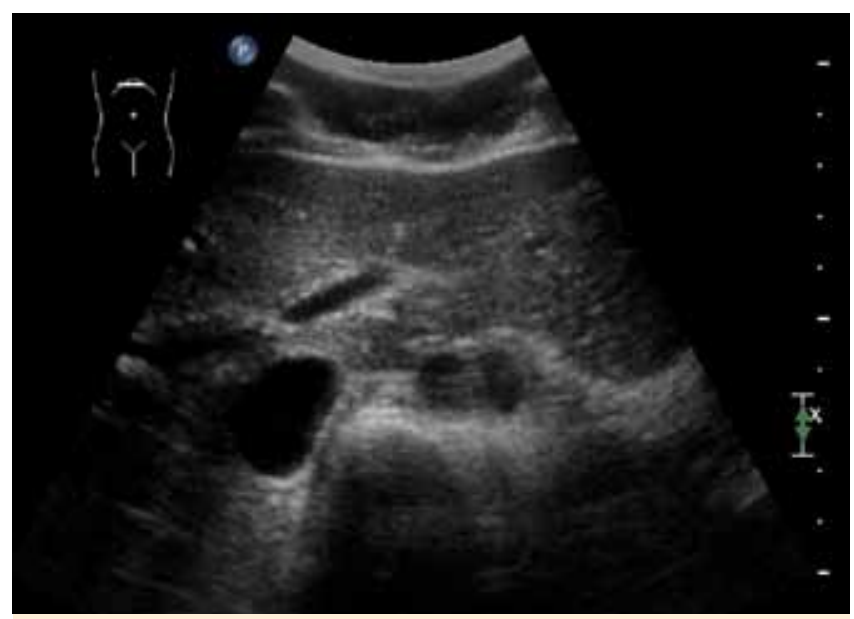

Abb. 1 Transversalschnitt des oberen Abdomens im B-Bild. Die Aorta scheint verdoppelt.

Fig. 1 Transverse view of the upper abdomen in B-mode shows a duplicated aorta.

\section{Fallbericht}

$\nabla$

Eine 27 Jahre alte Frau, die wegen eines ein Jahr zuvor diagnostizierten mediastinalen Hodgkin-Lymphoms in Behandlung war, wurde zu einer abdominalen Ultraschalluntersuchung überwiesen, die Teil einer Begutachtung am Ende der Therapie war. Sie hatte einen athletischen Körperbau, war $176 \mathrm{~cm}$ groß und wog $72 \mathrm{~kg}$ (BMI =23). Die klinische Untersuchung war unauffällig. Es bestand eine komplette Remission und die Laboruntersuchungen wiesen keine Abnormitäten auf.

\section{Duplication of Abdominal Aorta: a very Rare Congenital Anomaly but a Common Ultrasound Artifact}

\section{Introduction \\ $\nabla$}

During an ultrasound examination, sound waves are directed to a particular part of the body, and the resulting reflections of echoes are used to generate images of the explored anatomical structures. These echoes may be altered by multiple interferences: tissues of differing composition, density, and attenuation, as well as interfaces between tissues of differing shape, size, and orientation. These alterations may cause numerous artifacts that are likely to lead to diagnostic errors if they are not recognized.

We report here on an artifact of a duplication image, which is easily recognized by experienced sonologists but may be challenging for inexperienced examiners.

\section{Case report \\ $\nabla$}

A 27-year-old woman, treated for mediastinal Hodgkin's lymphoma diagnosed 1 year earlier, was referred for an abdominal ultrasound as part of an end-of-treatment assessment. She had an athletic build, with a high of $176 \mathrm{~cm}$ and a weight $72 \mathrm{~kg}(\mathrm{BMI}=23)$. The clinical examination was normal. The adenopathies had disappeared, and the laboratory tests did not reveal any abnormalities.

The abdominal ultrasound showed an image of a duplication of the abdominal aorta when the probe was placed transversally across the epigastric region (oFig. 1). In color Doppler mode, a synchronous pulsatile flow was observed in the two vessel lumens (oFig. 2). Not only the aorta was duplicated, but also the

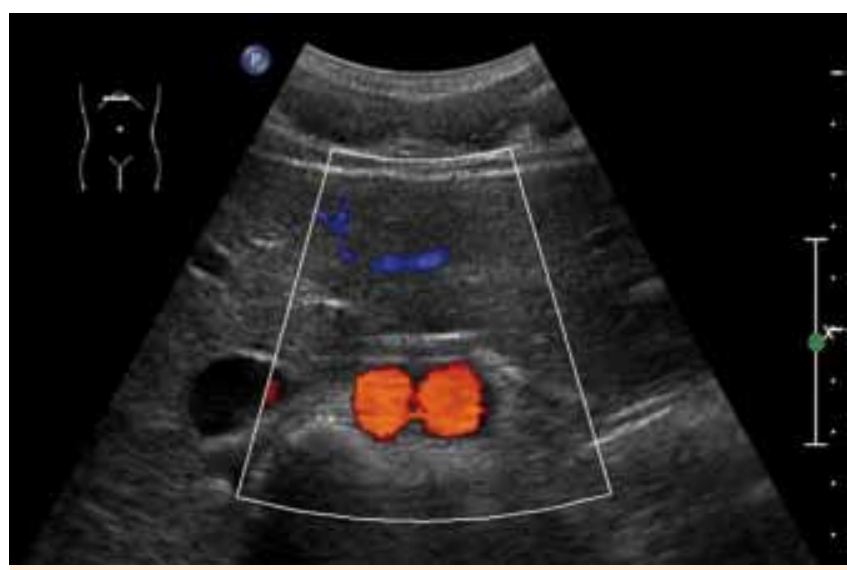

Abb. 2 Transversalschnitt des oberen Abdomens im Farbdoppler. Die 2 Lumina der Aorta sind mit Farbe gefüllt.

Fig. 2 Transverse view of the upper abdomen in color Doppler shows the two aortic lumens filled with color. 


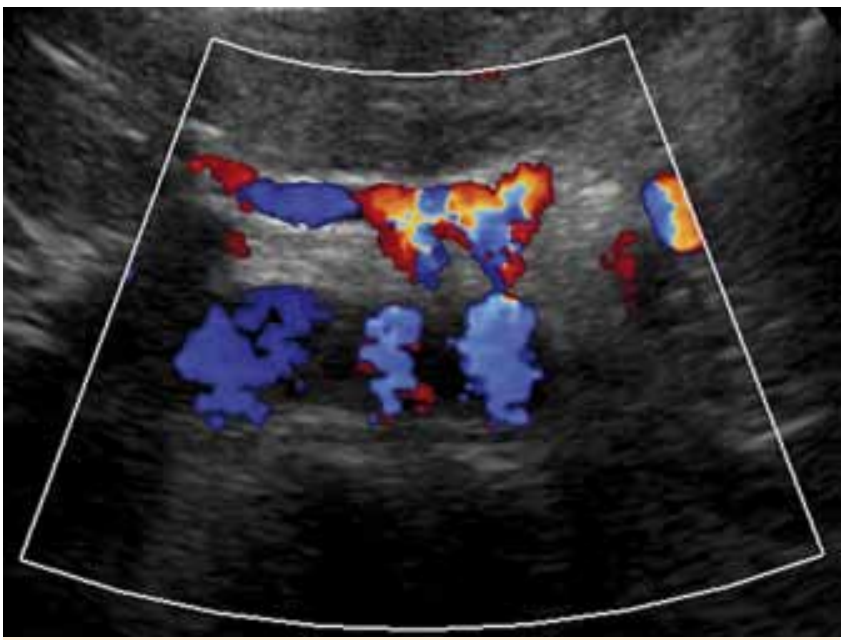

Abb. 3 Vergrößerter Transversalschnitt des oberen Abdomens im Farbdoppler. Zwei Truncus Coeliacus stammen aus den Aorten und bilden einen arteriellen Bogen.

Fig. 3 Enlarged transverse view of the upper abdomen in color Doppler shows two celiac trunks originating from the aortas and forming an arterial arch.

Der Ultraschall zeigte das Abbild einer Verdoppelung der Bauchaorta wenn der Schallkopf transversal zur Oberbauchregion plaziert wurde ( $\triangle$ Abb. 1). Im Farbdoppler-Modus wurde in beiden Gefäßlumina eine synchron pulsierende Strömung beobachtet ( $\odot$ Abb. 2). Dabei erschien nicht nur die Aorta verdoppelt, sondern auch der Truncus coeliacus mit Darstellung eines Arterienbogens zwischen beiden Stämmen ( $\triangle$ Abb. 3 ) und der Arteria mesenterica superior ( $\triangle$ Abb. 4). Wurde der Schallkopf um $90^{\circ}$ gedreht, um Sagittalschnitte zu erhalten, schien das Aortenlumen echogenes Material zu enthalten während den Schallkopf über den oberen Teil des Abdomens bewegt wurde. Auf den Transversalschnitten verschwand das doppelte Bild, sobald der Schallkopf seitlich nach links oder rechts verlagert wurde ( $\triangle$ Abb. 5). Die vorherigen Computertomografie-Untersuchungen hatten nie eine Anomalität der Bauchaorta ergeben.

\section{Diskussion}

Die Bauchaorta entwickelt sich in der 4. Woche der Embryogenese während der Verbindung des Aortenlumens beider dorsaler Bauchaorten zwischen den Ebenen T4 und L4 (Schoenwolf G, Bleyl S, Brauer P et al. Larsen's Human Embryology. 4th ed. London: Churchill Livingstone; 2008). Bis jetzt wurde der nicht erfolgte Zusammenschluss der Bauchaorta nur 2-mal in der Literatur erwähnt, einmal 1975 von Mosquera et al. in einem argentinischen Artikel (Mosquera JE, Micarelli R. Rev Fac Cienc Med Cordoba. 1975; 33: 89-94) und ein 2. Mal 1977 bei Trubnikov et al. in einem russischen Review (Trubnikov GV, Naimark DA, Nalobina MS et al. ] Klin Med (Mosk). 1977; 55: 138-141). Obwohl beide Fallbeschreibungen gut dokumentiert wurden, wurden sie von Glodny et al. in einem Artikel aus dem Jahr 2009 infrage gestellt, in dem über einen anderen Typ einer sehr seltenen Veränderung der Bauchgefäße berichtet wurde, nämlich einer persistierenden, singulären Umbilicalarterie (Glodny B, Henninger B, Hofmann et al. Cases J 2009; 2: 65). Diese Autoren nahmen an, dass die ersten anatomischen Beschreibungen der Verdopplung lediglich auf einer fehlerhaften Interpretation chronischer Aortendissektionen beruhten. celiac trunk with visualization of an arterial arch between the two trunks ( $\odot$ Fig. 3) and the superior mesenteric artery ( $\odot$ Fig. 4). When the probe was turned $90^{\circ}$ in order to acquire sagittal slices, the aortic lumen seemed to contain echogenic material, while the probe was moved across the superior part of the abdomen. On transverse slices, the image of duplication disappeared when the probe was shifted laterally to the right or left (oFig. 5). The previous computed tomography (CT) scans had never revealed any abnormality of the abdominal aorta.

\section{Discussion}

$\nabla$

The abdominal aorta develops during the $4^{\text {th }}$ week of embryogenesis, during the fusion of the aortic lumen of the two dorsal abdominal aortas between the T4 and L4 levels (Schoenwolf G, Bleyl $\mathrm{S}$, Brauer P et al. (editors). Larsen's Human Embryology. $4^{\text {th }}$ ed. London: Churchill Livingstone; 2008). To date, the non-fusion of the abdominal aorta has been reported only twice in the literature, once in 1975 by Mosquera et al. in an Argentinean article (Mosquera JE, Micarelli R. Rev Fac Cienc Med Cordoba. 1975; 33 : 89-94), and a second time in 1977 by Trubnikov et al. in a Russian review (Trubnikov GV, Naimark DA, Nalobina MS et al. Klin Med (Mosk) 1977; 55: 138-141). Although the 2 case descrip-

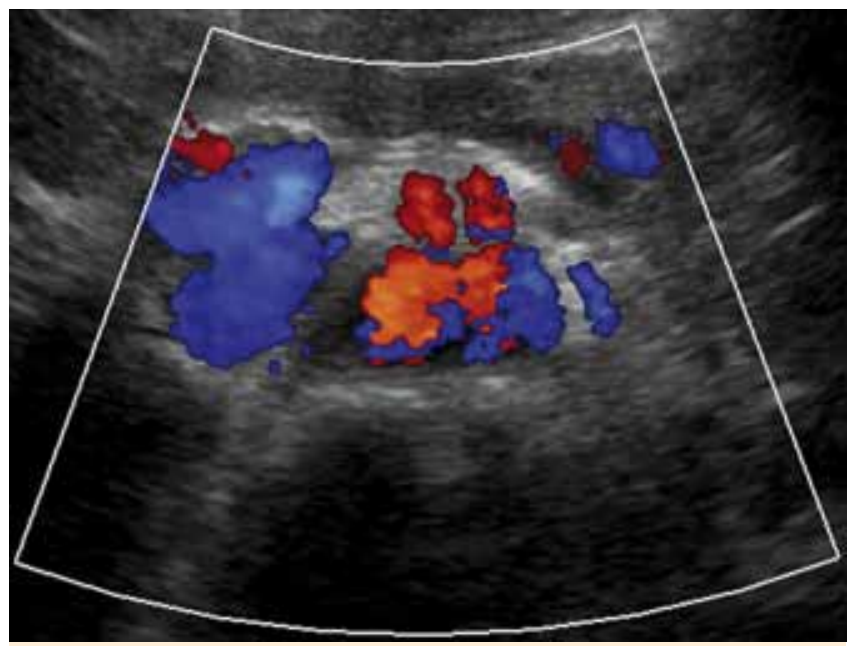

Abb. 4 Vergrößerter Transversalschnitt des oberen Abdomens im Farbdoppler. Eine Arteria Mesenterica Superior entspringt aus jedem Aortenlumen.

Fig. 4 Enlarged transverse view of the upper abdomen in color Doppler shows one superior mesenteric artery originating from each aortic lumen.

tions were well documented, they were questioned by Glodny et al. in an article from 2009 reporting on another type of very rare variation of the abdominal vessels, namely a persistent impaired umbilical artery (Glodny B, Henninger B, Hofmann Ket al. Cases J. 2009; 2: 65). These authors believed that the first anatomical descriptions of duplication only corresponded to an erroneous interpretation of chronic aortic dissections.

When performing ultrasound examinations in young patients using probes with a large radius of curvature, it is not uncommon to observe images of a "double" upper abdominal aorta (Heyne JP. Ultraschall in Med. 2000; 21: 145-147, Mandelstam SA, Brockley C. Pediatr Radiol. 2004; 34: 508). The origin of this duplication artifact was explained in detail by Vandeman et al. in 1990 (Vandeman FN, Meilstrup JW et al. Invest Radiol. 1990; 25: 658-663). 
Führt man Ultraschalluntersuchungen bei jungen Patienten unter Verwendung von Schallkopfen mit großem Kurvenradius durch, ist es nicht ungewöhnlich, Bilder einer „doppelten“ oberen Bauchaorta zu beobachten (Heyne JP. Ultraschall in Med 2000; 21: 145-147, Mandelstam SA, Brockley C. Pediatr Radiol 2004; 34: 508). Der Ursprung dieses Duplikationsartefakts wurde bei Vandeman et al. 1990 (Vandeman FN, Meilstrup JW, Nealey PA. Invest Radiol 1990; 25: 658-63) im Detail erklärt. Diese Autoren führten eine experimentelle Studie durch, in der sie zeigen konnten, dass die anatomischen Strukturen der Bauchdecke zu einem gewissen Ausmaß zur Entstehung dieser Artefakte beitragen. Das Fettgewebe zwischen den geraden Bauchmuskeln spielt eine Schlüsselrolle bei der Verdopplung der akustischen Bündel, während die Muskeln nur kleinere Deformationen verursachen.

Diese Doppelbilder sind auf die Brechung des akustischen Bündels zurückzuführen, wenn es schräg einen Grenzbereich passiert, der 2 Materialien mit unterschiedlichen Schallübertragungsgeschwindigkeiten trennt (Sauerbrei EE. J Ultrasound Med. 1985; 4: 29-34). Diese Richtungsänderung des Bündels wird durch das Snell-Descartes-Gesetz gemäß der folgenden Gleichung definiert:

\section{$\sin \Theta 2 / \sin \Theta 1=\mathrm{V} 2 / \mathrm{V} 1$}

Hierbei entspricht $\Theta 1$ dem Einstrahlwinkel, $\Theta 2$ dem Brechungswinkel und V1 und V2 der Schallübertragungsgeschwindigkeiten in den verschiedenen Materialien. Indem das Ultraschallgerät davon ausgeht, dass die Schallwelle sich in einer geraden Linie über die Gewebe bewegt, erstellt es ein Echo-Bild, das von der Brechung direkt neben der aktuellen Position deformiert wird. In unserem Fall wird das Bündel in beide Richtungen durch das Prisma der Bauchdecke verändert und als Folge wird das Bild gedoppelt. Das Verhältnis der Übertragungsgeschwindigkeit zwischen Fett und Muskeln $\left(1450 \mathrm{~m} \cdot \mathrm{s}^{-1} / 1580 \mathrm{~m} \cdot \mathrm{s}^{-1}=0,91\right)$ ist kleiner als zwischen Weichgewebe und Muskeln $\left(1540 \mathrm{~m} \cdot \mathrm{s}^{-1}\right.$ $\left.11580 \mathrm{~m} \cdot \mathrm{s}^{-1}=0.97\right)$ oder zwischen Fett und Weichgewebe $\left(1450 \mathrm{~m} \cdot \mathrm{s}^{-1} / 1540 \mathrm{~m} \cdot \mathrm{s}^{-1}=0,94\right)$. Da sich dieses Verhältnis auf den Sinus von Winkeln bezieht, ist leicht zu verstehen, dass die Winkeldifferenz das Maximum erreicht, wenn die Differenz der

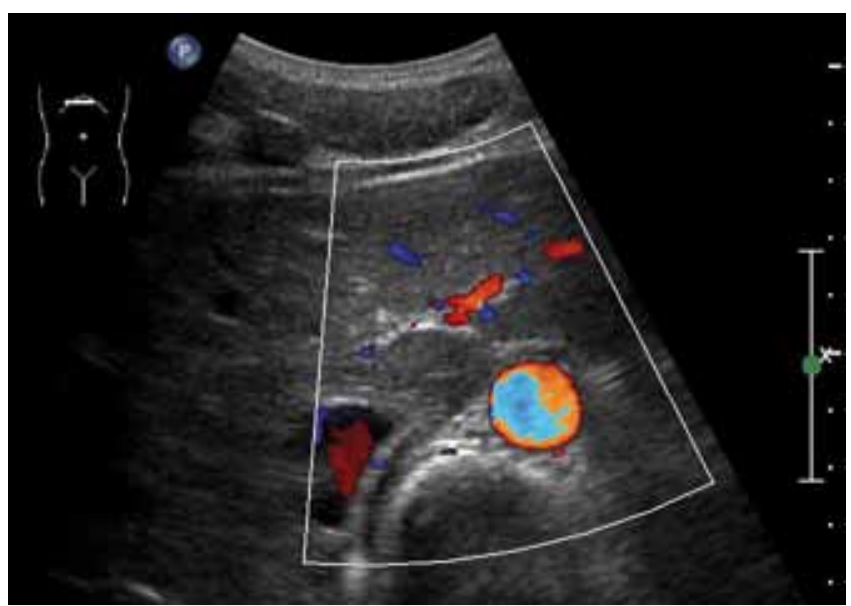

Abb. 5 Transversalschnitt des oberen Abdomens im Farbdoppler nach einer leichter Lateralisation des Schallkopfes nach rechts. Die 2 Lumina der Aorta sind verschwunden und nur eines bleibt sichtbar, mit Farbe gefüllt.

Fig. 5 Transverse view of the upper abdomen in color Doppler after a tinny sliding of the probe to the right. The two channels have disappeared and only one subsists, filled with color.
These authors performed an experimental study, which allowed them to demonstrate that the anatomic structures of the abdominal wall contribute to some extent to the formation of these artifacts. The adipose tissue located between the rectus abdominus muscles plays a key role in the duplication of the acoustic bundles, whereas the muscles cause only minor deformation.

These duplication images are due to the refraction of the acoustic bundle when it passes obliquely across an interface separating two materials with differing sound transmission velocities ( Sauerbrei EE. J Ultrasound Med. 1985; 4: 29-34). This change in the direction of the bundle is defined by Snell's law according to the following equation:

$\sin \Theta 2 / \sin \Theta 1=\mathrm{V} 2 / \mathrm{V} 1$

where $\Theta 1$ corresponds to the incident angle, $\Theta 2$ to the refraction angle, and V1 and V2 to the sound transmission velocities in the different materials. Since ultrasound equipment presumes that the acoustic bundle moves in a straight line across tissues, it reconstructs an echo image deformed by the refraction next to the current position. In our case, the bundle is deformed in both directions by the prism of the abdominal wall resulting in image duplication. The ratio of the transmission velocities is lower between fat and muscle $\left(1450 \mathrm{~m} \cdot \mathrm{s}^{-1} / 1580 \mathrm{~m} \cdot \mathrm{s}^{-1}=0.91\right)$ than between soft tissue and muscle $\left(1540 \mathrm{~m} \cdot \mathrm{s}^{-1} / 1580 \mathrm{~m} \cdot \mathrm{s}^{-1}=0.97\right)$ or between fat and soft tissue $\left(1450 \mathrm{~m} \cdot \mathrm{s}^{-1} / 1540 \mathrm{~m} \cdot \mathrm{s}^{-1}=0.94\right)$. As this ratio applies to the sinus of angles, it is easily understood that the difference in angles is at its maximum when the difference in transmission velocities is at its highest, i. e. between fat and muscles. Therefore, for an incident angle of $30^{\circ}$, the refraction angles for transition from muscle to fat, muscle to soft tissue, and soft tissue to fat are $27.1^{\circ}, 29.0^{\circ}$, and $28.0^{\circ}$, respectively (oFig. 6 ). This phenomenon applies to sound waves used to reconstruct blackand-white images as well as pulsed and color Doppler images. It is therefore possible to obtain a spectrum of frequency in the two aortas, and to fill them in color Doppler.

When using a large convex probe for abdominal exploration, it is difficult to move it laterally in the subxiphoid region due to the chondrocostal cartilages. The probe stays centered on the acoustic prism, with a slantwise oriented ultrasound beam, and the double image persists during craniocaudal movement. When the probe is turned $90^{\circ}$, the phenomenon persists in the transverse plane. Closer to the umbilicus, the probe may be moved laterally, and the duplication image disappears.

This phenomenon can appear everywhere where an acoustic prism forms. This is especially true in the lower abdominal region where false cases of twin pregnancies (Sauerbrei EE. J Ultrasound Med. 1985 Jan; 4: 29-34) or double intrauterine devices (Muller N, Cooperberg PL, Rowley VA et al. J Ultrasound Med. 1984; 3: 515-519) have been reported.

\section{Conclusions}

$\nabla$

The frequency and singularity of these artifacts highlight that a sound understanding of the physics of ultrasound is necessary when performing ultrasound examinations. More than with any other imaging technique, the interactions between the bundle and tissues can distort the image. The sonologist must be aware 


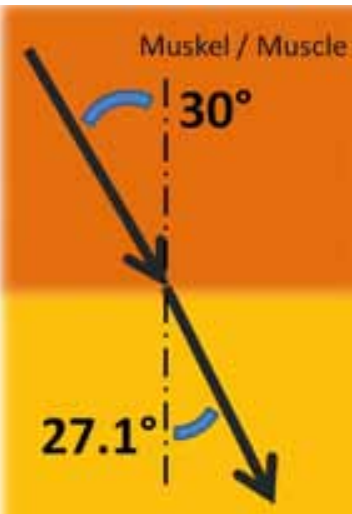

Fett/Fat

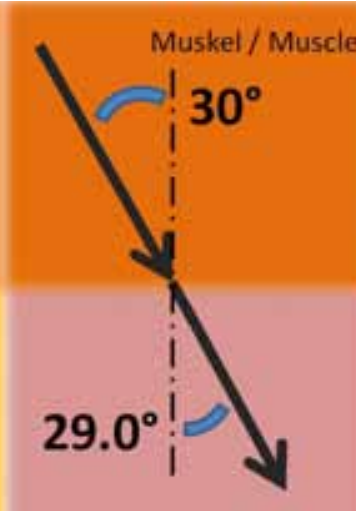

Weichgewebe / Soft tissue

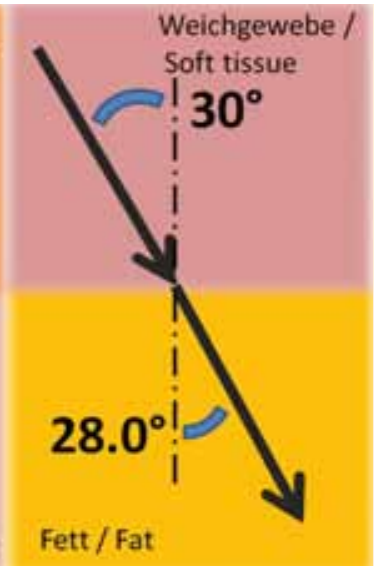

Abb. 6 Brechung des Schallbündels am Übergang zweier Medien mit unterschiedlichen Schallübertragungsgeschwindigkeiten.

Fig. 6 Refraction of the ultrasound beam at the interface between media of different sound transmission velocities.
Übertragungsgeschwidigkeiten am höchsten ist, wie es zwischen Fett und Muskeln der Fall ist. Deshalb beträgt bei einem Einstrahlwinkel von $30^{\circ}$ der Brechungswinkel für Übergang zwischen Muskeln und Fett, Muskeln und Weichgewebe, und zwischen Weichgewebe und Fett jeweils $27,1^{\circ}, 29,0^{\circ}$ und 28, $0^{\circ}$ ( $\odot$ Abb. 6). Dieses Phänomen betrifft Schallwellen zur Erzeugung von Schwarz-Weiß-Bildern ebenso wie gepulste und Farbdoppler-Bilder. Es ist deshalb möglich, ein Frequenzspektrum in beiden Aorten zu erhalten sowie sie im Farbdoppler zu füllen.

Verwendet man einen großen konvexen Schallkopf zur Untersuchung des Abdomens, ist es wegen der Rippenknorpel schwierig, ihn distal des Sternumendes seitlich zu bewegen. Der Schallkopf bleibt auf das akustische Prisma zentriert, mit schräg orientierten Schallwellen, und das Doppelbild bleibt während einer kraniokaudalen Bewegung bestehen. Mit einem $90^{\circ}$ gedrehten Schallkopf, bleibt die Brechung der Schallwellen in der Transversalebene. Näher am Nabel kann der Schallkopf seitlich bewegt werden und das Doppelbild verschwindet.

Dieses Phänomen kann überall auftreten, wo sich ein akustisches Prisma ausprägt. Dies trifft vor allem für die untere Bauchregion zu, sodass über falsche Zwillingsschwangerschaften (Sauerbrei EE. J Ultrasound Med 1985; 4: 29-34) oder doppelte Intrauterinpessare (Muller N, Cooperberg PL, Rowley VA et al. J Ultrasound Med. 1984; 3: 515-519) berichtet wurde.

\section{Schlussfolgerungen \\ $\nabla$}

Die Häufigkeit und Einzigartigkeit der Artefakte erfordern ein fundiertes Verständnis der Ultraschall-Physik für die Vermeidung von Fehlern bei der Ultraschalldiagnostik. Im Vergleich mit anderen bildgebenden Techniken können die Wechselwirkungen zwischen Ultraschall und Geweben zu variantenreichen Bildartefakten führen. Der Ultraschalldiagnostiker muss den Einfluss dieser Wechselwirkungen auf die resultierenden Ultraschallbilder kennen.

Angesichts der heutigen rasanten Expansion der Ultraschalltechnologie bei vielen unterschiedlichen Interessengruppen ist es wichtig, dass diese grundsätzlichen Kenntnisse der Physik zur Grundausbildung jedes Ultraschalldiagnostikers gehören müssen, unabhängig davon, ob das Interesse in der Untersuchung des Abdomens, einer komplexen Gefäßuntersuchung oder einem schnellen Screening in Notaufnahmen besteht. Unzureichende Physikkenntnisse können sowohl bei der Diagnose als auch bei der Therapie zu zahlreichen Irrtümern führen. of the influence of these interactions on the resulting ultrasound images.

Given today's rapid expansion of ultrasound technology among multiple groups with differing interests, fundamental knowledge of the physics of ultrasound must be included in the basic education of every sonologist, regardless of whether the field of interest is the exploration of the abdomen, complex vascular investigations, or quick screening in emergency departments. Insufficient knowledge of the physics may lead to numerous errors in both diagnosis and treatment.

\section{Video: Look at www.thieme-connect.de/ejournals}

\section{J.-Y. Meuwly, A.-S. Knopfli, G. Gullo, Lausanne, Switzerland Jean-Yves.Meuwly@chuv.ch}

